DOI: 10.46340/eppd.2021.8.1.23

Anna Osmolovska, ORCID: https://orcid.org/0000-0002-8795-8910

Yelyzaveta Pohoreliuk,

ORCID: https://orcid.org/0000-0001-6233-7280

Artem Oleksienko

ORCID: https://orcid.org/0000-0002-3891-3281

Vasyl' Stus Donetsk National University, Vinnytsia, Ukraine

\title{
INFORMATION PRESENCE \\ OF REGIONAL DEVELOPMENT STATE \\ POLICY IMPLEMENTATION IN MEDIA
}

\author{
Анна Осмоловська, \\ Єлизавета Погорелюк, \\ Артем Олексієнко \\ Донецький національний університет імені Василя Стуса, м. Вінниця, Україна
}

\section{СПЕЦИФІКА ВИСВІТЛЕННЯ РЕАЛІЗАЦЇ̈ ДЕРЖАВНОЇ ПОЛІТИКИ РЕГІОНАЛЬНОГО РОЗВИТКУ У МЕДІА}

The article is devoted to building a model of effective communication between the Cabinet of Ministers of Ukraine, Vinnytsia Regional State Administration and district state administrations / territorial communities in the context of the implementation of the state regional policy of Ukraine and the process of decentralization in Ukraine. The authors used research methods and techniques such as media audit of official information resources of public authorities at national, regional and district levels, a survey of residents in the format of a formalized "face-to-face" interview, the method of correlations, and the method of modeling implementation of state regional policy in the media. The present methods allowed offering an adaptive model of communications at the level of "state-region-district" with the aim to strengthen the information component of the implementation of state regional policy in Vinnytsia region. At the first stage of the research (monitoring of news on the official websites of public authorities) it has been found that the lack of reflection of key strategic goals of regional policy at the national level might indicate a low focus of higher authorities on social issues. However, a fairly high percentage of own content at the regional and district levels, which reflects the implementation of regional development policy, indicates the activity of the region and communities in the creation and maintenance of news items at the level of Vinnytsia region. The second stage of the research (study of public opinion) has showed that the level of awareness of residents of three Vinnytsia region districts about the implementation of state regional policy at the regional level is insufficient. There are three information realities in the region that partially intersect. It concerns the information agenda of the Cabinet of Ministers of Ukraine, the agenda of Vinnytsia Regional State Administration and district state administrations, and the information reality of ordinary citizens. At the third stage of the research, a graphical fixation of the current state of affairs in public communications and development of normative (ideal) model of adaptive public communications organization for Vinnytsia Regional State Administration based on the data obtained in the first two stages, has been made.

Keywords: information presence, information space, state policy of regional development, communication model, strategic goals of state regional policy, axis "state-region-district". 
Постановка проблеми. Децентралізація в Україні була запроваджена у 2014 році. Ії перший етап реалізації можна вважати успішним. Однак, існує кілька ключових проблем, які гальмують цей процес за сучасних умов. Серед них - нефективність комунікації між громадами, органами державної влади та інститутами місцевого самоврядування. Наявність високого рівня інформаційної присутності успішних кейсів децентралізації та поширення релевантної інформації, системний взаємозв'язок влади і громади дозволяють досягти високого рівня взаємопорозуміння на останньому етапі реформи. Поширення такої інформації через офіційні та неофіційні канали комунікації є запорукою формування концепції політики «знизу», без якої успішної децентралізації не може бути. Тому побудова ефективної комунікаційної моделі «держава-область-район/територіальна громада (ТГ)» стане безпосередньою запорукою успішності цього процесу. Ця актуальність набуває ще більшої переконливості в контексті системного партнерства влади, громадянського сектору, освіти та науки.

Дослідження, що представлено, $є$ результатом співпраці здобувачів вищої освіти (авторів роботи) та науковців з інститутом громадянського суспільства ГО «Центр аналізу та розвитку громадських комунікацій «ДІАЛОГ» та продуктом залучення авторів до проєкту «Розробка моделі державних комунікацій Вінницької ОДА: регіональний вимір» ${ }^{1}$.

Стан розробленості теми міждисциплінарний. Слід звернути увагу, як на роботи дослідників у сфері децентралізації, так і дослідження з теорії комунікацій. Серед науковців, метою дослідження яких $\epsilon$ аналіз досвіду впровадження реформи децентралізації в світі можна виокремити роботи Е. Карташова, В. Григор'єва, М. Долішнього, Н. Камінської, А. Матвієнко, П. Щенси, М. Примуша. У більшій мірі питання децентралізації влади досліджується фахівцями в галузі юридичних наук- О. Батанов, В. Бороденюк, В. Копейчіков, В. Сенчук, В. Чіркін та інші. Проте державна політика децентралізації та регіональний розвиток $є$ одними з головних предметів дослідження політологічної науки. Це доводять роботи М. Баймуратова, В. Заблоцького, В. Кампи, Н. Нижник, М. Студенікіної та інших.

Стратегічний і соціокультурний потенціал території робить іiі політичним інститутом i соціальною спільнотою одночасно. Взаємозв'язок соціокультурного, комунікаційного та владного чинників розвитку регіонів $\epsilon$ необхідною умовою залучення територіальних громад до інформаційнокомунікаційного середовища та можливості впливу на прийняття політичних рішень уякості повноцінного актора політики. Таким чином, регіони, виконуючи функції агрегирування та артикуляції інтересів держави, місцевої влади, громад, бізнесу, мають спиратися на дієву комунікаційну модель у просуванні державної політики регіонального розвитку.

Серед дослідників, які займаються вивченням теми конструювання медіадискурсу в Україні О. Жеребко, Л. Климанська, В.Кулик, П.Леньо, Р. Офіцинський, П. Романюк, В. Сичова. Авторами наукових робіт, що присвячені можливості застосування комунікацій для формування брендів регіонів є В. Ляпоров, Д. Рябих, В. Тарнавський, Л. Шульга, В. Домніна, О. Шевченко, С. Тихомірова.

Мета дослідження полягала у спробі сформувати модель ефективної комунікації між Кабінетом Міністрів України (далі - КМУ), Вінницькою обласною державною адміністрацією (далі - ВінОДА) і районними державними адміністраціями (далі- РДА) / територіальними громадами (далі - ТГ) в контексті реалізації державної регіональної політики України.

Основні методи дослідження. Методика медіa-ayдиту офіційних інформаційних ресурсів органів державної влади національного, обласного та районного рівнів (сайти КМУ, ОДА, РДА) дозволила визначити специфіку інформаційної присутності ключових напрямів Стратегії регіонального розвитку до 2020 року $^{2}$ та Стратегії регіонального розвитку

\footnotetext{
${ }^{1}$ Офіційний сайт ГО «Центр аналізу та розвитку громадських комунікацій «ДІАЛОГ» (2021).

Проєкт «Розробка моделі державних комунікацій Вінницької ОДА: регіональний вимір».

$<$ http://www.centerdialog.org/2021/02/blog-post_8.html?m=1> (2020, січень, 15).

Команда проєкту:

Голова правління ГО «Центр «ДІАЛОГ», кандидат політичних наук - Сергій Бондаренко

Від Донецького національного університету імені Василя Стуса:

Перший проректор, доктор політичних наук, професор - Тетяна Нагорняк

Керівник спеціальності Політологія, доктор політичних наук, професор - Микола Польовий

Аспірантка кафедри політології та державного управління - Анна Осмоловська

Здобувачі вищої освіти ОП «Прикладна політологія та політичні технології» - Слизавета Погорелюк, Артем

Олексіснко, Гончарук Анна.

2 Державна стратегія регіонального розвитку на період до 2020 року, 2014 (Верховна Рада України).

Офіиійний сайт Верховної Ради України <https://zakon.rada.gov.ua/laws/show/385-2014-\%D0\%BF\#Text>

(2020, листопад, 15).
} 
до 2027 року ${ }^{1}$ на національному, обласному та районному рівнях, а також Стратегії збалансованого регіонального розвитку Вінницької області на період до 2020 року $^{2}$ та Стратегії збалансованого регіонального розвитку Вінницької області на період до $2027^{3}$ року на обласному та районному рівнях. Вивчення громадської думки було проведено шляхом опитування мешканців трьох районів Вінницької області, а саме Жмеринського, Іллінецького та Калинівського. Анкетування в районах проводилось в форматі формалізованого інтерв'ю «face-to-face». Це дозволило оцінити рівень поінформованості громадян про стратегічні цілі, факти і напрями впровадження державної регіональної політики, визначити пріоритетні канали інформації та сформувати соціальний запит на теми, що цікавлять громаду. Метод кореляцій дозволив встановити взаємозв'язки між заявленими стратегічними цілями і напрямами впровадження державної регіональної політики в інформаційному просторі офіційних ресурсів органів влади, рівнем поінформованості мешканців трьох районів Вінницької області та запитами на теми, що є для них важливими. Моделювання впровадження в медіа державної регіональної політики дозволило запропонувати адаптивну модель комунікацій на рівні «держава-регіон-район/ТГ» (з урахуванням результатів медіа-аудиту та оцінки громадської думки населення) для зміцнення інформаційної складової реалізації державної регіональної політики на Вінниччині.

Основні результати дослідження. Дослідження проходило у кілька етапів відповідно до поставленої мети. Першим етапом став моніторинг новин офіційних сайтів органів державної влади. Предметом медіа-аудиту була інформаційна присутність напрямів реалізації державної регіональної політики на офіційних ресурсах органів державної влади та місцевого самоврядування, а медіа-картою - офіційний сайт Кабінету Міністрів України ${ }^{4}$, офіційний сайт Вінницької обласної державної адміністрації, офіційний сайт Жмеринської районної державної адміністрації ${ }^{6}$ Калинівської районної державної адміністрації ${ }^{7}$ та Іллінецької районної державної адміністрації ${ }^{\circ}$.

За результатами медіа-аудиту було встановлено, що стратегічні цілі впровадження державної регіональної політики на національному рівні, що втілюються у Стратегії регіонального розвитку до 2020 року, лише на 55\% (6 з 11 цілей) відображені у Стратегії збалансованого регіонального розвитку Вінницької області на період до 2020 року. Решта напрямів (5 з 11) відображають специфіку саме національного рівня реалізації державної регіональної політики. Наприклад, «Посилення міжгалузевої координації в процесі планування та реалізації державної регіональної політики», «Підвищення ролі та функціональних можливостей міст у подальшому розвитку регіонів» та ін.

Стратегія збалансованого регіонального розвитку Вінницької області на період до 2020 року включає в себе 26 стратегічних цілей, 6 (20\%) з яких співпадають 3 цілями впровадження державної регіональної політики національного рівня. Решта цілей (19) відображають специфіку обласного рівня реалізації державної політики регіонального розвитку. Наприклад, «Забезпечення розвитку інфраструктури територіальних громад області», «Інформаційна сфера Вінницької області» та ін.

Стратегічні цілі впровадження державної регіональної політики на національному рівні, що втілюються у Стратегії регіонального розвитку до 2027 року, на 60\% (10 з 17 цілей) відображені у Стратегії збалансованого регіонального розвитку Вінницької області на період до 2027 року. Решта

${ }^{1}$ Державна стратегія регіонального розвитку на 2021-2027 роки, 2020 (Верховна Рада України).

Офіційний сайт Верховної Ради Украӥни <https://zakon.rada.gov.ua/laws/show/695-2020-\%D0\%BF\#Text> (2020, листопад, 15).

${ }^{2}$ Стратегія збалансованого регіонального розвитку Віннищької області на період до 2020 року, 2015

(Вінницька обласна рада). Офіційний сайт Вінницької обласної ради <https://vinrada.gov.ua/proekt-strategi\%

D0\%87-regionalnogo-rozvitku-vinnicko\%D0\%87-oblasti-na-period-do-2020-roku.htm> (2020, листопад, 15).

${ }^{3}$ Стратегія збалансованого регіонального розвитку Вінницької області на період до 2027 року, 2020

(Вінницька обласна рада). Офіиійний сайт Віннищької обласної ради $<\mathrm{https://vinrada.gov.ua/strategiya-}$ zbalansovanogo-regionalnogo-rozvitku-vinnickoi-oblasti-na-period-do-2027-roku.htm> (2020, листопад, 15).

${ }^{4}$ Офіційний сайт Кабінету Міністрів України (2020). Головна сторінка $<$ https://www.kmu.gov.ua/>

(2020, грудень, 10).

${ }^{5}$ Офіційний сайт Вінницької ОДА (2020). Головна сторінка $<$ http://www.vin.gov.ua/> (2020, грудень, 10).

${ }^{6}$ Офіційний сайт Жмеринської РДА (2020). Головна сторінка $<$ https://zhmerynka-rda.gov.ua/>

(2020, грудень, 10).

${ }^{7}$ Офіційний сайт Калинівської РДА (2020). Головна сторінка $<$ http://kalynivka-rda.gov.ua/> (2020, грудень, 10).

${ }^{8}$ Офіційний сайт Іллінецької РДА (2020). Головна сторінка $<$ http://illrda.gov.ua/rda> (2020, грудень, 10). 
напрямів (7 із 17) не є у значній мірі актуальними для регіонального розвитку Вінницької області, ураховуючи специфіку регіону. Наприклад, «Створення умов для реінтеграції тимчасово окупованої території Автономної Республіки Крим та м. Севастополя, тимчасово окупованих територій у Донецькій та Луганській областях в український простір», «Сталий розвиток промисловості», «Стимулювання центрів економічного розвитку (агломерації, міста)» та ін.

Стратегія збалансованого регіонального розвитку Вінницької області на період до 2027 року включає в себе 22 стратегічні цілі, 10 (45\%) з яких співпадають з цілями впровадження державної регіональної політики національного рівня. Решта цілей (12) відображають специфіку обласного рівня реалізації державної політики регіонального розвитку. Наприклад, «Забезпечення єдності і згуртованості в громадах», «Збереження та раціональне використання водних ресурсів» та ін.

Деякі напрями Стратегій регіонального розвитку до 2020 та 2027 року не відображені на обласному рівні через те, що ініціатором їх реалізації здебільшого виступають органи державної влади, а не місцевого самоврядування. Наприклад, «Інституційне забезпечення регіонального розвитку» (2020) чи «Розбудова потенціалу суб’єктів державної регіональної політики» (2027).

Відсутність відображення ключових стратегічних цілей впровадження регіональної політики обласного рівня на рівні національному свідчить про низьку орієнтованість вищих органів влади на висвітлення соціально-побутових тем (туризм, екологічна свідомість, захист прав дітей, розвиток молоді та спорту). Проте запит на ці теми існує на рівні громад.

Моніторинг офіційних сайтів показав, що ці медіа-ресурси (сайти КМУ, ВінОДА та трьох РДА) $\epsilon$ офіційними каналами інформаційного супроводу впровадження державної політики регіонального розвитку на всіх рівнях, що втілюється в офіційних документах - Стратегіях регіонального розвитку та Стратегіях збалансованого регіонального розвитку Вінницької області.

Частота подачі новин на офіційних сайтах КМУ, ВінОДА, Жмеринської РДА, Калинівської РДА та Іллінецької РДА спадає відповідно до рівня реалізації політики регіонального розвитку. Стрічка новин сайту КМУ в середньому - 16-18 новин на день, сайту ВінОДА - 9-11, сайту Жмеринської РДА - 0-3 новин на день, сайту Калинівської РДА - 6-9 новин на день, сайту Іллінецької РДА - 1-4 новин на день. Таким чином, інформація, яка продукується на державному рівні, дозовано ретранслюється на обласному рівні, і в обмеженій кількості висвітлюється в районах.

Співпадіння і розбіжності інформаційної присутності фактів і напрямів впровадження державної регіональної політики на національному, обласному та районному рівнях політики свідчать про наявність розбіжностей у відображенні ключових напрямів на усіх трьох рівнях. Така розбіжність між національним та обласним рівнями впровадження державної політики регіонального розвитку свідчить про втрату (цілеспрямовану або ні) частини акцентів органів державної влади на рівні місцевого самоврядування або про специфіку регіону. А недостатність присутності стратегічних цілей та запитів обласного рівня на національному свідчить або про замовчування базових потреб громад, або про недостатнє висвітлення чи значущість власних меседжів обласного рівня.

Тим не менш, достатньо високий відсоток власного контенту обласного та районного рівнів відображення реалізації політики регіонального розвитку свідчить про активність регіону та громад у створенні та супроводі інформаційних приводів на рівні Вінниччини.

Наступним етапом дослідження став аналіз рівня поінформованості мешканців 3 питань реалізації державної політики регіонального розвитку.

За результатами анкетування в районах, яке проводилось в форматі формалізованого інтерв'ю «face-to-face», було встановлено, що рівень обізнаності мешканців трьох районів Вінницької області (Іллінецький, Жмеринський та Калинівський) про реалізацію державної регіональної політики на обласному рівні $\epsilon$ недостатнім. Більшість опитаних необізнані взагалі або обізнані слабко з вказаної теми. Такий стан речей несе загрозу нерозуміння напрямків розвитку держави, області, їх стратегічних та оперативних завдань, а також кореляції інтересів особи та держави через формування та забезпечення узгодженої інформаційної політики.

Відсутність кореляції між станом обізнаності респондентів про задачі регіонального розвитку та стратегічних цілей державної регіональної політики, що ініційовані КМУ, вказує на неефективність інформаційного супроводу реформ. Єдиною темою, що корелює, є «забезпечення комфортного та безпечного життєвого середовища» (25\% доля матеріалів на сайті КМУ за цією темою, 21\% - знання теми серед респондентів). Це потенційно свідчить про те, що національна інформаційна політика не враховує інтереси споживачів інформації, а популяризація тем, що представляють інтерес для влади, реалізується формально. 
Схожі тенденції і в регіоні. Напрями регіонального розвитку, про які знають респонденти, не відповідають цілям, що висвітлює облдержадміністрація на своєму сайті. Це свідчить про певний дисбаланс між тим, що і як просувається ВінОДА/РДА з пріоритетними для громади каналами комунікацій та їхніми запитами на «точки росту» ТГ. Проте слід зазначити специфіку інформування громади про хід державної регіональної політики. Якщо Калинівська РДА ретранслює інформацію сайту ВінОДА, то Жмеринська та Іллінецька намагаються формувати власний порядок денний, створюючи адаптивний контент, що міг би стати в нагоді для поширення кращих практик на рівні області.

Слабким місцем інформаційної політики ОДА на обласному рівні $є$ канали комунікації 3 населенням. Згідно результатів анкетування, мешканці області отримують інформацію про політику регіонального розвитку з каналів, на які ОДА практично не має впливу. Пріоритетним каналом для споживачів інформації є національне телебачення (59\%), соціальна мережа Facebook (34\%) та регіональне телебачення (33\%). Канали комунікації, на які раніше мала вплив ОДА, наприклад, обласні та місцеві газети, практично не користуються попитом. Це також стосується офіційних сайтів ОДА та РДА. Ризиком є те, що мешканці Вінницької області формують свою комунікативну реальність 3 джерел, що не керуються ОДА . Для вирішення цієї проблеми слід зосередитись на нових каналах комунікацій, зокрема на власній активності у соціальних мережах та підтримці місцевих (локальних) онлайн 3МI.

Напрями, що респонденти визначили для себе як пріоритетні, слід використати, як базові при побудові інформаційної стратегії та політики паралельно з тими, що представляють інтерес для просування стратегічних пріоритетів та цілей державної регіональної політики. Такий підхід дозволить забезпечити узгодженість як інтересів державних органів влади, так і громадян в інформаційному просторі. Наразі можна констатувати, що в області існує дві-три інформаційні реальності, які частково перетинаються. Це стосується інформаційного порядку денного Кабінету міністрів України, порядку денного ВінОДА і РДА та інформаційної реальності звичайних громадян. В межах кожного з цих інформаційних просторів розуміння сьогодення та майбутнього кардинально відрізняються, що створює певний когнітивний дисонанс у громадян.

У рамках дослідження здійснено спробу узагальнити виявлені проблемні точки процесів медіакомунікації Кабінету міністрів України, ВінОДА та РДА щодо реалізації державної регіональної політики за допомогою побудови формалізованих моделей цього процесу.

Модель поточного стану державних комунікацій КМ України, Вінницької ОДА та РДА щодо стратегічних цілей регіонального розвитку відображає наступне:

Наразі 25\% інформаційних повідомлень КМУ України присвячені темам, пов'язаним із темами державної стратегії регіонального розвитку.

Серед інформаційних повідомлень на сайті Вінницької ОДА лише 43 \% повідомлень присвячені проблемам державної регіональної політики. Причому Вінницька ОДА транслювала через свої інформаційні ресурси 6311 ключових цілей державної Стратегії регіонального розвитку до 2020 p., та 8 із 17 цілей Стратегії регіонального розвитку до 2027 p.

Сайт Вінницької ОДА транслював також найчастіше лише 16 із 26 ключових цілей Стратегії збалансованого регіонального розвитку Вінницької області на період до 2020 р. (і ще 4 цілі лише згадувались в обмеженій кількості матеріалів сайту) та також 16 із 22 ключових цілей Стратегії збалансованого регіонального розвитку Вінницької області на період до 2027 р. (і також ще 4 цілі згадувались в незначній кількості матеріалів).

На сайтах РДА, взятих до аналізу, спостерігається співпадіння згадок лише 4 цілей Стратегії збалансованого регіонального розвитку Вінницької області до 2020 p. та 6 цілей Стратегії збалансованого регіонального розвитку Вінницької області до 2027 p.

Водночас слід зазначити намагання двох РДА з числа досліджуваних - Калинівської та Іллінецької- надавати інформацію, що корелює із стратегічними цілями національного рівня державної регіональної політики. Їх сайти містять матеріали, що стосуються, відповідно, 9 та 7 стратегічних цілей державної національної політики. Крім того, Іллінецька та Жмеринська РДА демонструють намагання створювати власний порядок денний та власний адаптивний контент. Водночас лише одна з РДА (Іллінецька), судячи з результатів опитування, є успішною у спробах відповідати на інформаційний попит громади.

На кожному кроці трансляції тем державної та обласної стратегій регіонального розвитку відбувається втрата до 50 \% тем відповідних стратегій. Зворотній зв'язок від жителів районів до РДА майже не простежується, а зворотній зв'язок від жителів районів до ВінОДА, згідно із наявними 
даними, фактично не існує. Аналіз наявності та якості зворотнього зв'язку між ВінОДА та КМУ України виходить за межі дослідження.

Зафіксована інформованість не більше $10 \%$ населення щодо деяких тем державної та обласної стратегій регіонального розвитку свідчить про явну недостатність комунікаційних зусиль ВінОДА та РДА. Вочевидь, ВінОДА потребує ревізії наявних каналів інформування та кардинального їх вдосконалення та, можливо, розширення їх номенклатури. Для більш широкого розповсюдження інформації щодо державної регіональної політики, організації конструктивного діалогу з населенням інститути державної влади та місцевого самоврядування мали б задіяти інші ресурси та заходи із орієнтації на інтереси громадян.

Інформаційний контент сайту ВінОДА містив 55\% інформації, пов'язаної із цілями державної регіональної політики, визначеної в Стратегії КМУ до 2020 р. та, відповідно 45\% інформації, присвяченої цілям Стратегії збалансованого регіонального розвитку Вінницької області до 2020 р. Певні зміни відбулись після прийняття Стратегій регіонального розвитку до 2027 p.

Представляється необхідним розширення регіонального порядку денного в загальнодержавних комунікаціях до щонайменше $50 \%$ та в комунікаціях ОДА щонайменше до $80 \%$, а в перспективі до 100\%. Пропоноване розширення регіональної складової в інформаційному порядку денному КМУ випливає із важливості як реформи децентралізації, так і вцілому регіонального розвитку в загальному розвитку держави. Тому автори дослідження пропонують, що не менше $50 \%$ усієі інформації КМ України, що присвячена питанням впровадження державної регіональної політики, має корелювати з регіональним контекстом. «Регіональний контекст» має бути адаптивним, та включати як цілі, визначені в Стратегії ВінОДА, так і потреби громад, періодично та регулярно 3'ясовувані Кабінетом міністрів України за посередництва ВінОДА та РДА (на малюнку моделі канали отримання інформації щодо громадської думки показані стрілками з пунктиром).

Необхідною є організація каналів зворотного зв'язку в напрямку «населення - РДА - ВінОДА КМУ». Причому потреби населення мають артикулюватись та агрегуватись на, відповідно, районному та обласному рівнях.

Інформаційний порядок денний районних адміністрацій (або керівництва ТГ) має враховувати не менше $80 \%$ тем державної та регіональної стратегії, а також спиратись на інформаційний попит мешканців району та максимально враховувати його.

Висновки та перспективи. Офіційними документами, що регламентують державну регіональну політику, є Стратегія регіонального розвитку та Стратегія збалансованого регіонального розвитку Вінницької області. Офіційні сайти КМУ, ВінОДА та трьох обраних РДА були досліджені в якості офіційних каналів інформаційного супроводу державної регіональної політики і просування вищезазначених стратегічних документів за віссю «Держава - Регіон - Район».

Напрями реалізації державної регіональної політики, що закріплені в стратегічних документах і відображені на сайті КМУ, ретранслюються на ресурсах ВінОДА в обсязі 50\%. На рівень районів доходить менше 20\% національних меседжів. Це дозволяє констатувати відсутність цілеспрямованої інформаційної кампанії в частині впровадження державної регіональної політики в Україні. Зміст інформаційних практик ВінОДА полягає в тому, що вона, дублюючи інформацію національного рівня, доповнює ії̈ власним контентом на етапі трансляції на рівень районів.

Специфіка інформування ТГ про ключові напрями регіонального розвитку виглядає наступним чином: - Калинівська РДА має найвищу активність висвітлення новин на сайті, але ці новини здебільшого дублюють меседжі ВінОДА;- Жмеринська РДА демонструє найвищий показник інформаційної присутності цих напрямів, ретранслюючи матеріал національного i обласного рівнів. Відносно низькій рівень інформаційної присутності цих напрямів на сайті Іллінецької РДА компенсується власним контентом локальних практик, що сприяє більшому розумінню реформ громадою.

Рівень обізнаності мешканців трьох ТГ Вінницької області про реалізацію державної регіональної політики та обласної політики регіонального розвитку є недостатнім. Проте системне вивчення громадської думки щодо запиту на інформацію про регіональний розвиток є підставою для покращення діалогу ВінОДА з ТГ та напрацювання локального контенту, що може стати в нагоді в частині поширення кращих практик Вінниччини на національному рівні.

Відсутність кореляції між станом обізнаності респондентів про задачі регіонального розвитку та стратегічними цілями державної регіональної політики, що ініційовані КМУ, вказує на необхідність пошуку ефективної моделі комунікацій щодо впровадження державної регіональної політики. 


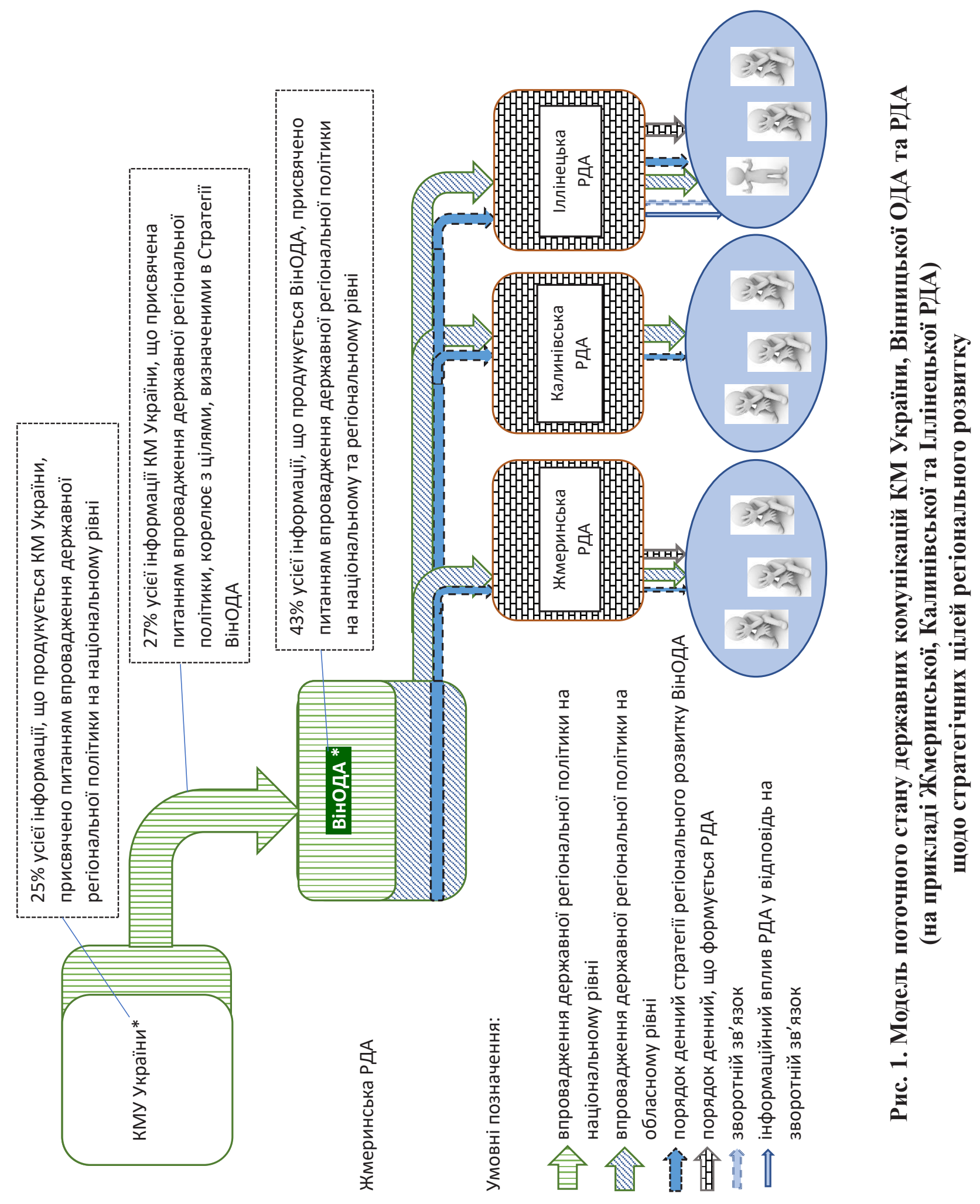




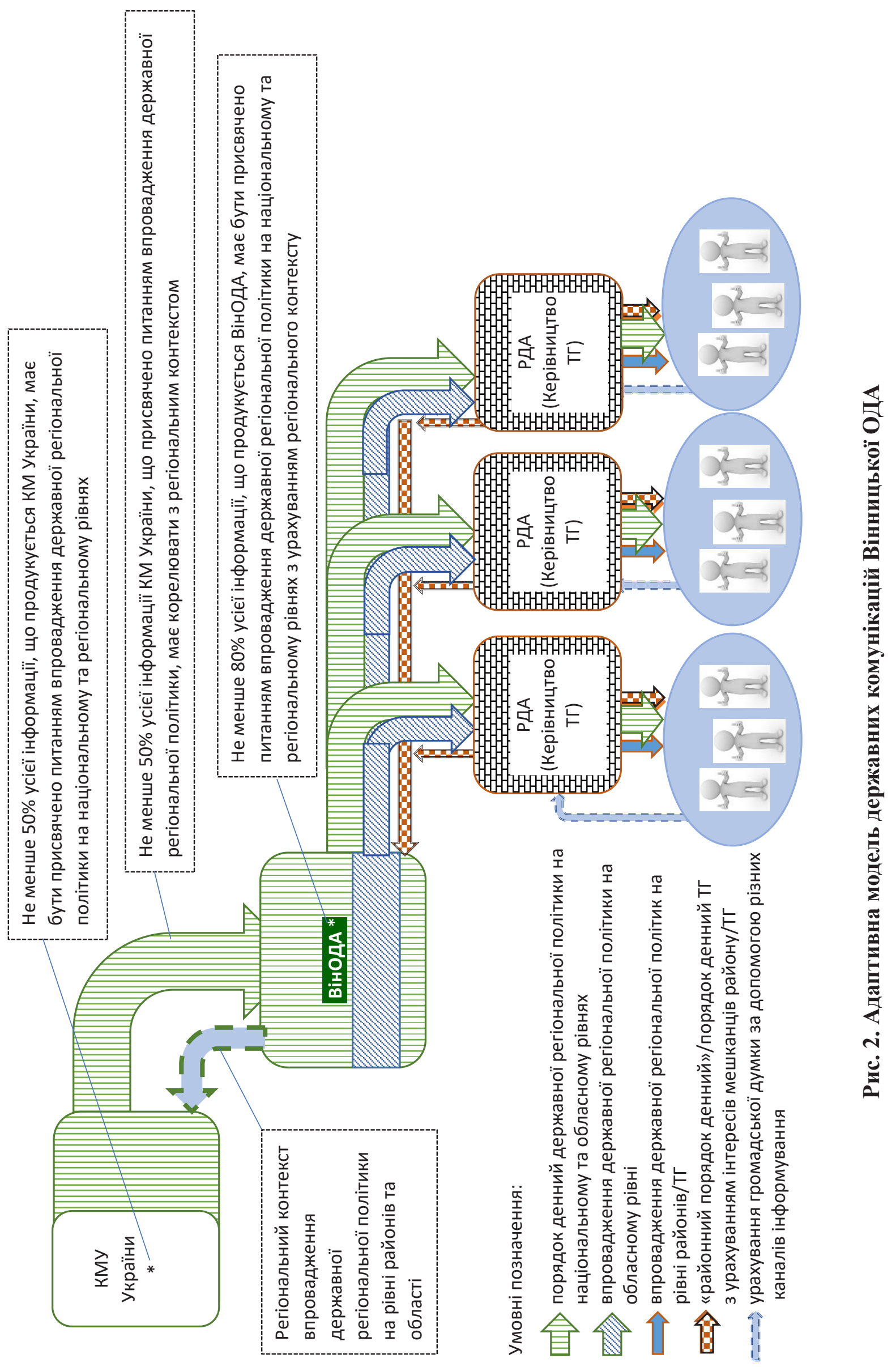


Для висвітлення напрямів впровадження державної регіональної політики на рівні області та ТГ було б корисно поширювати стратегічні цілі та меседжі, що сформовані в державній Стратегії регіонального розвитку та Стратегії збалансованого регіонального розвитку Вінницької області. У першу чергу потребує актуалізації наповнення офіційних сайтів ОДА та ТГ у зазначеному контексті. На думку мешканців ТГ альтернативними каналами інформації про розвиток регіону $\epsilon$ Facebook, YouTube, інтернет-видання та загальноукраїнське телебачення. Варто розглянути можливість збільшення інформаційної присутності регіону на національних телеканалах, в соціальних мережах та на радіо.

Місцеві органи державної влади при побудові ефективної інформаційної політики може виконувати роль своєрідного комунікаційного концентратора (хабу) між національним та районним рівнями, формуючи зворотній зв'язок між ТГ і державою в частині реалізації державної політики регіонального розвитку.

\section{References:}

1. Derzhavna stratehiya rehionalnoho rozvytku na 2021-2027 roky, 2020 (Verkhovna Rada Ukrayiny) [State Strategy for Regional Development for 2021-2027, 2020 (Verkhovna Rada of Ukraine)]. Ofitsiynyy sayt Verkhovnoyi Rady Ukrayiny [Official site of the Verkhovna Rada of Ukraine] $<$ https://zakon.rada.gov.ua/laws/show/695-2020-\%D0\%BF\#Text> (2020, November, 15). [in Ukrainian].

2. Derzhavna stratehiya rehionalnoho rozvytku na period do 2020 roku, 2014 (Verkhovna Rada Ukrayiny) [State Strategy for Regional Development for the period up to 2020, 2014 (Verkhovna Rada of Ukraine)]. Ofitsiynyy sayt Verkhovnoyi Rady Ukrayiny [Official site of the Verkhovna Rada of Ukraine] $<$ https://zakon.rada.gov.ua/laws/show/385-2014-\%D0\%BF\#Text> (2020, November, 15). [in Ukrainian].

3. Ofitsiynyy sayt Vinnytskoyi ODA (2020) [Official site of Vinnytsia Regional State Administration (2020)]. Holovna storinka [Home page] <http://www.vin.gov.ua/> (2020, December, 10).

4. Ofitsiynyy sayt HO Tsentr analizu ta rozvytku hromadskykh komunikatsiy DIALOH (2021) [Official site of the NGO "Center for Analysis and Development of Public Communications DIALOGUE (2021)]. Proyekt Rozrobka modeli derzhavnykh komunikatsiy Vinnytskoyi ODA: rehionalnyy vymir [Project Development of a model of state communications of Vinnytsia Regional State Administration: regional dimension]. $<$ http://www.centerdialog.org/2021/02/blog-post_8.html?m=1> (2020, January, 15). [in Ukrainian].

5. Ofitsiynyy sayt Zhmerynskoyi RDA (2020) [Official site of Zhmerynka RSA (2020)]. .Holovna storinka [Home page] <https://zhmerynka-rda.gov.ua/> (2020, December, 10). [in Ukrainian].

6. Ofitsiynyy sayt Illinetskoyi RDA (2020) [Official site of Illinetskaya RSA (2020)]. Holovna storinka [Home page] $<$ http://illrda.gov.ua/rda $>$ (2020, December, 10). [in Ukrainian].

7. Ofitsiynyy sayt Kabinetu Ministriv Ukrayiny (2020) [Official site of the Cabinet of Ministers of Ukraine (2020)]. Holovna storinka [Home page] <https://www.kmu.gov.ua/> (2020, December, 10). [in Ukrainian].

8. Ofitsiynyy sayt Kalynivskoyi RDA (2020) [Official site of Kalinov RSA (2020)]. Holovna storinka [Home page] $<$ http://kalynivka-rda.gov.ua/> (2020, December, 10). [in Ukrainian].

9. Stratehiya zbalansovanoho rehiona'noho rozvytku Vinnytskoyi oblasti na period do 2020 roku, 2015 (Vinnytska oblasna rada) [Strategy of balanced regional development of Vinnytsia region for the period up to 2020, 2015 (Vinnytsia regional council)]. Ofitsiynyy sayt Vinnytskoyi oblasnoyi rady [Official site of Vinnytsia regional council] $<$ https://vinrada.gov.ua/proekt-strategi\%D0\%87-regionalnogo-rozvitku-vinnicko\%D0\%87-oblasti-na-period-do2020-roku.htm> (2020, November, 15). [in Ukrainian].

10. Stratehiya zbalansovanoho rehionalnoho rozvytku Vinnytskoyi oblasti na period do 2027 roku, 2020 (Vinnytska oblasna rada) [Strategy of balanced regional development of Vinnytsia region for the period up to 2027, 2020 (Vinnytsia regional council)]. Ofitsiynyy sayt Vinnytskoyi oblasnoyi rady [Official site of Vinnytsia regional council]<https://vinrada.gov.ua/strategiya-zbalansovanogo-regionalnogo-rozvitku-vinnickoi-oblasti-na-period-do2027-roku.htm> (2020, November, 15). [in Ukrainian]. 